The International Journal of Indian Psychology: Volume: 01 | Issue: 04 No. 2 | ISSN 2348-5396

\title{
An Analytical Study of Attitude toward Sexual Behavior among Graduate and Post-Graduate Student
}

\author{
Pancholi Haresh*
}

\begin{abstract}
ABSTARCT
In present investigation the man object was know the attitude of toward sexual behavior among graduate and post-graduate student. $2 \times 2 \times 2$ by factorial design by the use for the data collection, the scale of Dr. yashvirsinh was translated and standardize and used total 240 was randomly and stratified collected from the science college and arts college in Bhavnagar university. Further they was stratified of the basic of graduate and post graduate and malefemale. The statistical analysis the ' $F$ ' test for use the conclusion showed that the different of attitude toward sexual behavior was from significant between graduate and post graduate student $(\mathrm{F}=183)$. The different of attitude toward sexual behavior was from significant between male and female student $(\mathrm{F}=22.99)$. The different of attitude toward sexual behavior was found not significant between science stream and arts stream $(\mathrm{F}=1.32)$. The different of attitude toward sexual behavior was significant between education level and sex (1281.00). The different of attitude between sexual behavior was from significant 00.5 level between sex and stream $(\mathrm{F}=5.43)$. The different of attitude toward sexual behavior was found not significant between education level and stream $(\mathrm{F}=1.96)$. The different of attitude toward sexual behavior was found not significant between education level, gender and stream $(\mathrm{F}=1.47)$.
\end{abstract}

\section{INTRODUCATION :-}

Every year about 2,50,000 college students take a human sexuality course, according to a 1994 estimate (Moglia, 1994). A major assumption made by many who teach theses courses is that they result in significant changes in attitudes about sexuality, e.g., increased knowledge, greater understanding and tolerance of both one's own and others' behavior, etc. Despite the importance of such attitude change, relatively little work has been done on developing broad measures of attitude change with good psychometric properties, especially in recent years.

Sexual behavior in children has been the focus of increasing attention over the past decade, after the advent of research that demonstrated a consistent relationship between sexual abuse and sexual behavior in children. Although a broad range of sexual behaviors has been observed in normal children, further research is needed to expand the knowledge base of practicing pediatricians regarding what is normative about sexual behavior in children.

*Vyakhyata Sahayak : M.N.College, Visnagar, Dist; Mehsana, Gujarat 
Sexual behavior in children can be sorted into a number of categories, all of them having an adult behavioral correspondence. These include adherence to personal boundaries, exhibitionism, gender role behavior, self-stimulation, sexual anxiety, sexual interest, sexual intrusiveness, sexual knowledge, and voyeuristic behavior. Personal boundaries reflect the presumed interpersonal distance maintained by most people. Young children, who are just learning the culturally appropriate distance, may stand too close, rub against people, or casually touch their mother's breasts or father's genitals. Exhibitionistic behavior in children, deliberately exposing body parts to other children or adults, may also take the form of "playing doctor." Gender role behavior reflects the sex-typing of interests and behaviors seen in children, and self-stimulation subsumes masturbation as well as touching or rubbing different parts of the body to bring pleasure. Children may show excessive modesty or anxiety at displays of affection between parents or other individuals. Alternatively, children may be very curious and open regarding sexual matters, including interest in the opposite sex and interest in more mature television shows or videos.

Young people select friends whose attitudes about sex are consistent with their own attitudes. The effect of friends' attitudes on sexual behavior was stronger for females than for males. High-risk sexual behavior in adolescents appears to be influenced by the sexual attitudes of peers, and young people select friends whose attitudes about sex are consistent with their own attitudes. Researchers sought to determine how adolescents come to resemble their peers in risky attitudes and behaviors, attempting to learn whether they are encouraged by peers to adopt certain behaviors or gravitate toward others with similar attitudes and behaviors. They also examined the role of peer attitudes in the development of high-risk behaviors.

The study analyzed data on 1,350 15- to 18-year-old male and female students taking part in the National Longitudinal Study of Adolescent Health, a nationwide study of individual, peer, family, school, and community factors related to health. High-risk sexual behavior was defined by the number of partners with whom adolescents had intercourse without a condom. Other findings showed that adolescents choose new friends with attitudes that are similar to their own. Teens who believed that sex had undesirable consequences were likely to choose new friends and retain existing friends with similar attitudes. This occurred to a similar extent in males and females. Previous research focuses on deliberative, belief-based attitudes toward sexual risk behaviors. Sexual contexts, however, epitomize situations in which systematic retrieval of one's beliefs about condoms and HIV prevention might often be minimal. Recent theoretical advances suggest that in such contexts, behavior should be better predicted by implicit attitudes. Implicit sexual attitudes are evaluative responses that are automatically and effortlessly evoked by cues in a sexual situation and involve feelings rather than verbally articulated thought.

\section{THE RANGE OF TEENAGE SEXUAL BEHAVIOR NORMAL RANGE}

- Sexually explicit conversations with peers 
Obscenities and jokes within cultural norm

- Sexual innuendo, flirting and courtship

- Interest in erotica

- Solitary masturbation

- Hugging, kissing, holding hands

- Foreplay, (petting, making out, fondling) and mutual masturbation: Moral, social or familial

- rules may restrict, but these behaviors are not abnormal, developmentally harmful, or illegal

- when private, consensual, equal, and non-coercive.

- Monogamist intercourse: Stable monogamy is defined as a single sexual partner throughout adolescence. Serial monogamy indicates long-term (several months or years) involvement with a single partner which ends and is then followed by another

\section{YELLOW FLAGE}

Though many of these are not necessarily outside the range of behavior exhibited in teen peer groups, some evaluation and response is desirable in order to support healthy and responsible attitudes and behavior.

- Sexual preoccupation/anxiety (interfering in daily functioning)

- Pornographic interest

- Polygamist sexual intercourse/promiscuity-indiscriminate sexual contact with more than one partner during the same period of time.

- Sexually aggressive themes/obscenities

- Sexual graffiti (especially chronic and impacting individuals)

- Embarrassment of others with sexual themes

- Violation of others' body space

- Pulling skirts up/pants down

- Single occurrence of peeping, exposing with known peers

- Mooning and obscene gestures

\section{RED FLAGE}

- Compulsive masturbation (especially chronic or public)

- Degradation/humiliation of self or others with sexual themes

- Attempting to expose others' genitals

- Chronic preoccupation with sexually aggressive pornography

- Sexually explicit conversation with significantly young children

\section{METHOD :-}

\section{(i) Hypothesis :}

A. We do not found any difference of attitude toward sexual behavior between graduate and post graduate. 
B. We don't found any difference attitude toward sexual behavior between male and female.

C. We don't found any difference of attitude toward sexual behavior between student of science stream and student of arts stream.

D. We don't found any difference of attitude toward sexual behavior between education level and gender of student.

E. We don't found any difference of attitude toward sexual behavior between gender and stream of the students.

F. We don't found any difference of attitude toward sexual behavior between education level and stream of the students.

G. We don't found any difference of attitude toward sexual behavior among education level, gander and stream of the students.

\section{(ii) Sample :}

For the study of present research many college and department of Bhavnagar University. Was including of in universe. Researcher took sample from the universe in which he purpose fully selected Department of science, commerce management and Arts Stream of Bhavnagar University. The sample was taken by stratified random method. Total sample of 240 was taken from different commerce of Arts and science stream's student.

(iii) Tools :

(A) Individual information sheet :

Individual variable of student's like (a) Graduation and post graduation level (b) Gander-(male,female) (c) stream- (Arts,science) etc.

\section{(B) Scale of Sexual behavior attitude Measurement:}

Contracted by Dr.Yashvirsinh (1971) and Gujarati translation was done by Dr.Arvind Dungrani (2004) Reliability was found 0.70 through split half method 0.68 through spearman brown method.

\section{(iv) Procedure :}

The scale of attitude toward sexual behavior. The scale of made of two option. Option was in either in 'yes' or 'no'. This scale considered 40 sentence. In each 20 word positive and 20 word negative. The respond category have been provided each question. Response 'yes' mark ' 2 ' and response 'No' mark ' 1 '. The maximum possible score is 80 and the minimum possible score is 40.High score is to be interpreted as high attitude of sexual behavior and low score as low attitude of sexual behavior.

(v) statistics :

Here in this study the ' $\mathrm{F}$ '-Test was conducted as a statistical technique to prove the aim.

RESULT :-

\section{Table No : 1}

Showing the summary of ' $F$ ' ration on overall attitude of sexual behavior. (ANOVA-2x2x2)

\begin{tabular}{|c|r|r|r|r|r|}
\hline $\begin{array}{c}\text { Source of } \\
\text { Variation }\end{array}$ & $\begin{array}{c}\text { Sum of } \\
\text { square }\end{array}$ & $\mathrm{df}$ & $\begin{array}{c}\text { Mean sum } \\
\text { of square }\end{array}$ & 'F' ratio & $\begin{array}{c}\text { Level of } \\
\text { Significant }\end{array}$ \\
\hline A & 0.14 & 1 & 0.14 & 183 & 0.01 \\
\hline
\end{tabular}


The International Journal of Indian Psychology: Volume: 01 | Issue: 04 No. 2 | ISSN 2348-5396

\begin{tabular}{|c|r|c|r|r|r|}
\hline B & 589.06 & 1 & 589.06 & 22.93 & 0.01 \\
\hline $\mathrm{C}$ & 33.73 & 1 & 33.73 & 1.32 & N.S. \\
\hline $\mathrm{AxB}$ & 0.02 & 1 & 0.02 & 1281.00 & 0.01 \\
\hline $\mathrm{BxC}$ & 139.20 & 1 & 139.20 & 5.43 & 0.05 \\
\hline $\mathrm{AxC}$ & 13.10 & 1 & 13.10 & 1.96 & N.S. \\
\hline AxBxC & 75.18 & 2 & 37.59 & 1.47 & N.S. \\
\hline Wss & 5917.30 & 231 & 25.62 & - & - \\
\hline Total & 6767.73 & 239 & 28.32 & - & - \\
\hline
\end{tabular}

\section{DISCUSSION :-}

The null hypothesis is not accepted regarding student education level has we found significant different of sexual attitude toward sexual behavior between graduate and post graduate student. Has we can see concluding there is different of attitude to sexual behavior between graduate and post graduate level student. On post graduate level student we come where matured so this can be one the reason and different getting different.

In the reference at the general. We found significant different between male and female student. So the null hypotheses is rejected hear. We found different types of responses toward sexual behavior from male and female student. Show these different types of difference can be one of the reasons up getting different between attitude from male and female student.

We do not get in the difference attitude of sexual behavior between student of science stream and student of arts stream. So null hypotheses accepted hear. We can conclusive that the attitude sexual behavior was not officiated from the stream of student in this which student. In present $21^{\text {th }}$ century in the facility in advance of connected. We very quickly every stream of collected these educations is providing and ofcource there are getting. For there environment too.

As education level and sex point of view there is a significant difference in attitude of sex behavior in student. There for null hypothesis is unacceptable because of difference in sexual behavior of male and female we can conclude that according to educational level and sex there is a difference in attitude of sex behavior boys and girls get social, education and emotional maturity with increment in age there for they fill have a less attitude toward sex behavior.

As a sex and stream point of view there is a average significant difference is 0.05 level in student attitude of sex behavior. There for null hypothesis is unacceptable. Student which are not in science stream, generally they fill shame higher then the science student the reason is science stream student has knowledge about sexual behavior.

As a education level and education stream point of view there is a significant difference in attitude of sex behavior in student there is null hypothesis is acceptable due to the modern era there is a development in knowledge about sexual behavior. People looks on sex as a psychophysical necessity in stead of sin, shame, or abhorrence and it is depend on maturity of person. There is a no difference in attitude of sex behavior for science stream and arts streams student. because both get shame environment, friends, family and rules and regulation in society.

As a far as education level, sex and stream is concern there is a not significant average difference in attitude of sex behavior in student. There for the null hypothesis is acceptable in
(C) 2014 www.ijip.in
July-September 2014
106 | P a g e 
The International Journal of Indian Psychology: Volume: 01 | Issue: 04 No. 2 | ISSN 2348-5396

last few year. There is development in attitude of sexual behavior with development of roll of male and female in the new era the attitude of freedom from sexual relation between male and female is developed.

\section{CONCLUSION :-}

1. There is significant difference between graduate and post-graduate student toward attitude of sexual behavior. behavior.

2. There is significant difference between boys and girls toward attitude of sexual

3. There is no significant difference between science stream and arts stream toward attitude of sexual behavior.

4. There is significant difference between education level and sex toward attitude of sexual behavior.

5. There is significant difference between sex and educational stream toward attitude of sexual behavior.

6. There is no significant difference between education level and educational stream toward attitude of sexual behavior.

7. There is no significant difference between education level, sex and educational stream toward attitude of sexual behavior.

\section{REFERENCE :-}

1. Baxi M. and Other(1996), "Psychology of sex and Married Life", Viral Publication, Ahmedabad p.g.125.

2.Bhoptkar,C.T. and Other (1979), "Psychology and Statistics", Viral Production, Ahmedabad, p.g.121 to 125.

3. contractor,B.M.(1998), "Experimental Psychology and Statistics" Viral Producation, Ahmedabad, p.g.21,117,125

4. Dugrani,A.G. (2004), "A study attitude of sex Behavior among Married and Unmarried Male-Femal".

5. Dave,M.M. and Other (1977), Psychology and Married Life", B.S. Shah Publishing Ahmedabad.

6. Desai,Y.K. (1975), "Development Psychology", University Book Producation Board, Ahmedabad. P.g.255.

7.Dave,C.B. and Other (1994), "statistic in Psychology", Viral publication, Ahmedabad,p.g.45.

8. Fonseca,M. (1976), "All about your sex and Married Life”, New Delhi, Vikad Publishing House.

9. Hurlcok,E.B. (Tra.-S.C.Kanawala)(1975), "Developmental Psychology", University Book Production Board, Ahmedabad, Vol.II, p.g.239.

10. Kamdar,N.H. and Other (1997), "Person Adjustment Psychology", Parsav Pubkushing, Ahmedabad, p.g.131.

11. Mansuri,G.R. (2003-04), First Edition, "Manovignan-no-Shabdkosh", Mayur Publishing, Ahmedabad, p.g.234.

12. pinard. (1908), "Academy of Medicine of Paris", March-31.

13.Singh,Y. (1977), "Sex behavior attitude Inventory", National Psychology Corporation, Agra, p.g.1 to 10. 
The International Journal of Indian Psychology: Volume: 01 | Issue: 04 No. 2 | ISSN 2348-5396

14. Stone,H.W. and Stone, A.S.(1953), “A married manual”, Ch.9.

15. Trivedi,M.D. and Parekh,B.U.(1994), "Statistics in Education", University Book Production Board, Ahmedabad. P.g.-145.

16. Vyas,K.B. and Other(1993), “applied Psychology”, C.Jamanadas Company, Ahmedabad,p.g.326.

17. Westermark.(1905), "The origin and Development of Moralideas”, Elis Havloc-psychology of Sex, Vol-2. Part-3, Random House, New York, 378.
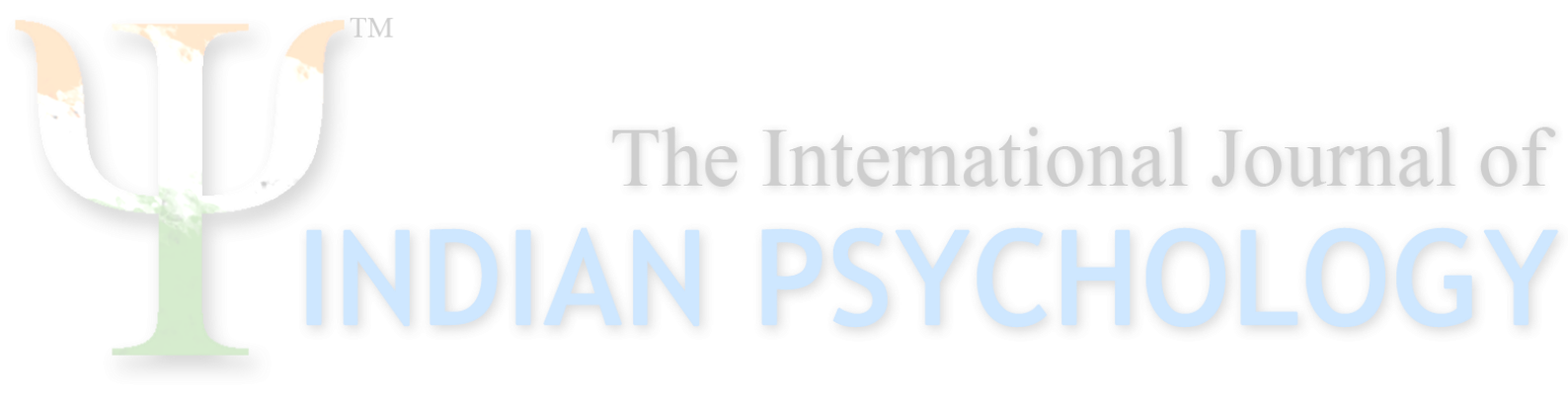